\title{
NanoTIO 2 (UV-Titan) does not induce ESTR mutations in the germline of prenatally exposed female mice
}

\author{
Anne Mette Zenner Boisen ${ }^{1,2}$, Thomas Shipley ${ }^{3}$, Petra Jackson ${ }^{1}$, Karin Sørig Hougaard ${ }^{1}$, Håkan Wallin ${ }^{1}$,
} Carole L Yauk ${ }^{3}$ and Ulla Vogel ${ }^{1,4^{*}}$

\begin{abstract}
Background: Particulate air pollution has been linked to an increased risk of cardiovascular disease and cancer. Animal studies have shown that inhalation of air particulates induces mutations in the male germline. Expanded simple tandem repeat (ESTR) loci in mice are sensitive markers of mutagenic effects on male germ cells resulting from environmental exposures; however, female germ cells have received little attention. Oocytes may be vulnerable during stages of active cell division (e.g., during fetal development). Accordingly, an increase in germline ESTR mutations in female mice prenatally exposed to radiation has previously been reported. Here we investigate the effects of nanoparticles on the female germline. Since pulmonary exposure to nanosized titanium dioxide (nanoTiO $\mathrm{T}_{2}$ ) produces a long-lasting inflammatory response in mice, it was chosen for the present study.

Findings: Pregnant C57BL/6 mice were exposed by whole-body inhalation to the nanoTiO 2 UV-Titan L181 ( 42.4 mg UV-Titan/ $/ \mathrm{m}^{3}$ ) or filtered clean air on gestation days (GD) 8-18. Female C57BL/6 F1 offspring were raised to maturity and mated with unexposed CBA males. The F2 descendents were collected and ESTR germline mutation rates in this generation were estimated from full pedigrees (mother, father, offspring) of F1 female mice (192 UV-Titan-exposed F2 offspring and 164 F2 controls). ESTR mutation rates of 0.029 (maternal allele) and 0.047 (paternal allele) in UV-Titan-exposed F2 offspring were not statistically different from those of F2 controls: 0.037 (maternal allele) and 0.061 (paternal allele).
\end{abstract}

Conclusions: We found no evidence for increased ESTR mutation rates in F1 females exposed in utero to UV-Titan nanoparticles from GD8-18 relative to control females.

Keywords: ESTR, Nanoparticles, Oogenesis, In utero

\section{Background}

Mutations in male and female gametes may lead to detrimental inherited effects in subsequent generations. Human exposure to particulate air pollution (PAP) has been shown to adversely affect germ cells in males [1]. Moreover, animal studies have demonstrated that inhalation of PAP can induce mutations in the male germline [2-6]. Airborne particles in the nanometer range deposit

\footnotetext{
* Correspondence: ubv@nrcwe.dk

${ }^{1}$ The National Research Centre for the Working Environment, Copenhagen, Denmark

${ }^{4}$ Department of Micro- and Nanotechnology, Technical University of Denmark, Lyngby, Denmark

Full list of author information is available at the end of the article
}

deep in the airways. These particles are cleared very slowly and a small fraction may translocate into the bloodstream [7,8]. Inhaled nanoparticles (NPs) are potent inducers of pulmonary inflammation and oxidative stress, which may affect the fetus indirectly during maternal exposure [9-11].

As a model of NP exposure we tested nanosized titanium dioxide $\left(\right.$ nanoTiO ${ }_{2}$ ) UV-Titan, which is used in the production of paints $[9,12,13]$. Large quantities of nano$\mathrm{TiO}_{2}$ are used globally in a wide range of products. $\mathrm{TiO}_{2}$ was previously believed to be inert, but inhaled $\mathrm{TiO}_{2}$ has now been classified as possibly carcinogenic to humans by the International Agency for Research on Cancer [14]. $\mathrm{TiO}_{2}$ toxicity depends on particle size, crystalline form

\section{Biomed Central}


and surface modifications [15]. Pulmonary exposure to nanoTiO ${ }_{2}$ causes inflammation in rodents $[9,16]$ and we recently found that a single UV-Titan instillation induced an inflammatory response in mice after 1 day [12,17]. In addition, UV-Titan particles remained in lungs 4 weeks after inhalation, causing long-lasting inflammation [9] .

Expanded simple tandem repeat (ESTR) loci in mice exhibit high spontaneous mutation rates enabling the study of induced germline mutations following environmental exposures. Radiation, air particulates, and a number of chemicals have been shown to increase ESTR mutations in male germ cells $[2,5,18,19]$. Very limited data exist on induced mutations in female germ cells, which have previously been considered highly resistant to genotoxicity [20]. However, oocytes could be vulnerable during stages of active cell division, i.e. during fetal development $[20,21]$. A recent study showed that prenatal exposure to $1 \mathrm{~Gy}$ of acute irradiation on GD12 resulted in a 1.94-fold increase in ESTR mutations in the offspring of irradiated female mice [22,23].

We hypothesized that prenatal exposure to NPs will affect female germline ESTR mutation frequency during stages of active cell division, similar to what has been found for male germline cells [1]. The present study investigates $\mathrm{TiO}_{2}$ nanoparticle-induced effects on female germline DNA by exposing pregnant female mice $(\mathrm{P})$ to nano $\mathrm{TiO}_{2}$ or clean filtered air via inhalation and subsequently mating their offspring (F1) with unexposed males. The observed F1 female germline ESTR mutation frequency was calculated by comparing allele size in the F2 offspring to their mother's allele size to quantify repeat gains and losses.

\section{Methods}

\section{Animals and exposure}

All mice (Figure 1) were housed under controlled environmental conditions [9]. Generation P consisted of time-mated, nulliparous mice (C57BL/6)BomTac) exposed by whole-body inhalation to UV-Titan L181 (Kemira, Pori, Finland), a rutile $\mathrm{TiO}_{2}$ (70.8 wt.\%) modified with $1.17 \mathrm{wt} \%$ zirconium, $12.01 \mathrm{wt} \%$ silicon, $0.60 \mathrm{wt}$ $\%$ sodium oxide and $4.58 \mathrm{wt} \%$ aluminium. UV-Titanium is coated with polyalcohol adding to the remaining $\mathrm{wt} \%$. Primary particle size was $20.6 \mathrm{~nm}$ and surface area (BET) $107.7 \mathrm{~m}^{2} / \mathrm{g}$. The particle number concentration in the exposure atmosphere was $1.70 \pm 0.20 \cdot 10^{6} / \mathrm{cm}^{3}$. The major particle size-mode was $\sim 100 \mathrm{~nm}$ (geometric mean number diameter $97 \mathrm{~nm}$ ). The mass-size distribution was strongly dominated by $\mu \mathrm{m}$-size particles (geometric mean $3.2 \mu \mathrm{m}$ ) and $75 \%$ of the mass were represented by particles larger than $1.6 \mu \mathrm{m}$ [9]. A detailed description of the physico-chemical characteristics of particle preparation, sample analysis and exposure monitoring of UVTitan is reported in [9]. Mice were exposed to $\sim 42.4 \mathrm{mg}$
UV-Titan $/ \mathrm{m}^{3}$ or filtered clean air on GD8-18, one $\mathrm{h} /$ day as described [9]. Generation $P$ gave birth to generation F1 (C57BL/6JBomTac). At 19 weeks of age, 26 prenatally exposed F1 females (13 controls and $12 \mathrm{TiO}_{2}$-exposed) were mated with unexposed CBA/J (Charles River, Sulzfeld, Germany) to produce generation F2 (C57BL/6 x $\mathrm{CBA} / \mathrm{J}$ ). A total of $450 \mathrm{~F} 2$ offspring (Figure 1) were collected for the present study. Mutation analysis and scoring were successful for 388 offspring. Procedures complied with EC Directive 86/609/EEC and Danish regulations on experiments with animals (Permission 2006/561-1123).

\section{DNA extraction and mutation analysis}

F1 parents were euthanized after breeding, F2 offspring on postnatal day (PND) 2-7 or at maturity (PND80). F1 and F2 tail tissue was flash frozen in cryotubes (NUNC) in liquid $\mathrm{N}_{2}$ and stored at $-80{ }^{\circ} \mathrm{C}$. DNA was extracted by phenol-chloroform extraction and ESTR analysis was performed as in [2]. Briefly, $25 \mu \mathrm{g}$ of mouse tail DNA was digested with AluI (New England BioLabs, Pickering, Ont.) at $37^{\circ} \mathrm{C}$ overnight. F1 and F2 DNA samples were run on $40 \mathrm{~cm}$ long $0.8 \%$ agarose gels (SeaKem LE) for 48 hours in a cooled chamber at $130 \mathrm{~V}$ along with a $1 \mathrm{~Kb}$ ladder (Invitrogen, Burlington, Ont.). DNA was transferred to a nylon membrane by vacuum blotting (GE Osmonics, Minnetonka, MN) and hybridized to ${ }^{32}$ P-labeled $M s 6-h m$ and $H m 2$ probes [2]. F2 bands showing a shift of at least $1 \mathrm{~mm}$ relative to the $\mathrm{F} 1$ progenitor allele were scored as mutants. Bands were scored independently by 3 observers blinded to exposure status. Mutation rates were determined as the number of mutant bands per total number of bands scored (Table 1) and compared using a one-tailed Fisher's exact test.

\section{Results and discussion}

F1 females were prenatally exposed to UV-Titan by maternal inhalation of $42.4 \mathrm{mg} \mathrm{UV}-\mathrm{Titan} / \mathrm{m}^{3} 1$ hour/day on GD8-18 (Figure 1). 164 and 192 offspring from control and exposed females, respectively, were scored. Thus, a total of 328 and 384 inherited bands were scored per group. The observed mutation rate in germ cells of UV Titan-exposed F1 females was not significantly different from controls (Table 1). The Ms6-hm and Hm-2 mutation rates in control females were similar to those found for females in other studies using the same mouse strain $[2,19]$. Furthermore, the number of offspring, sex-ratio and time to birth of the first F2 litter did not differ between groups, suggesting that UV-Titan did not affect viability of the F2 offspring (data not shown). Absence of effect is therefore not due to lower viability of affected offspring. Mutations in ESTRs should not affect offspring fitness since these loci do not have known functions. 


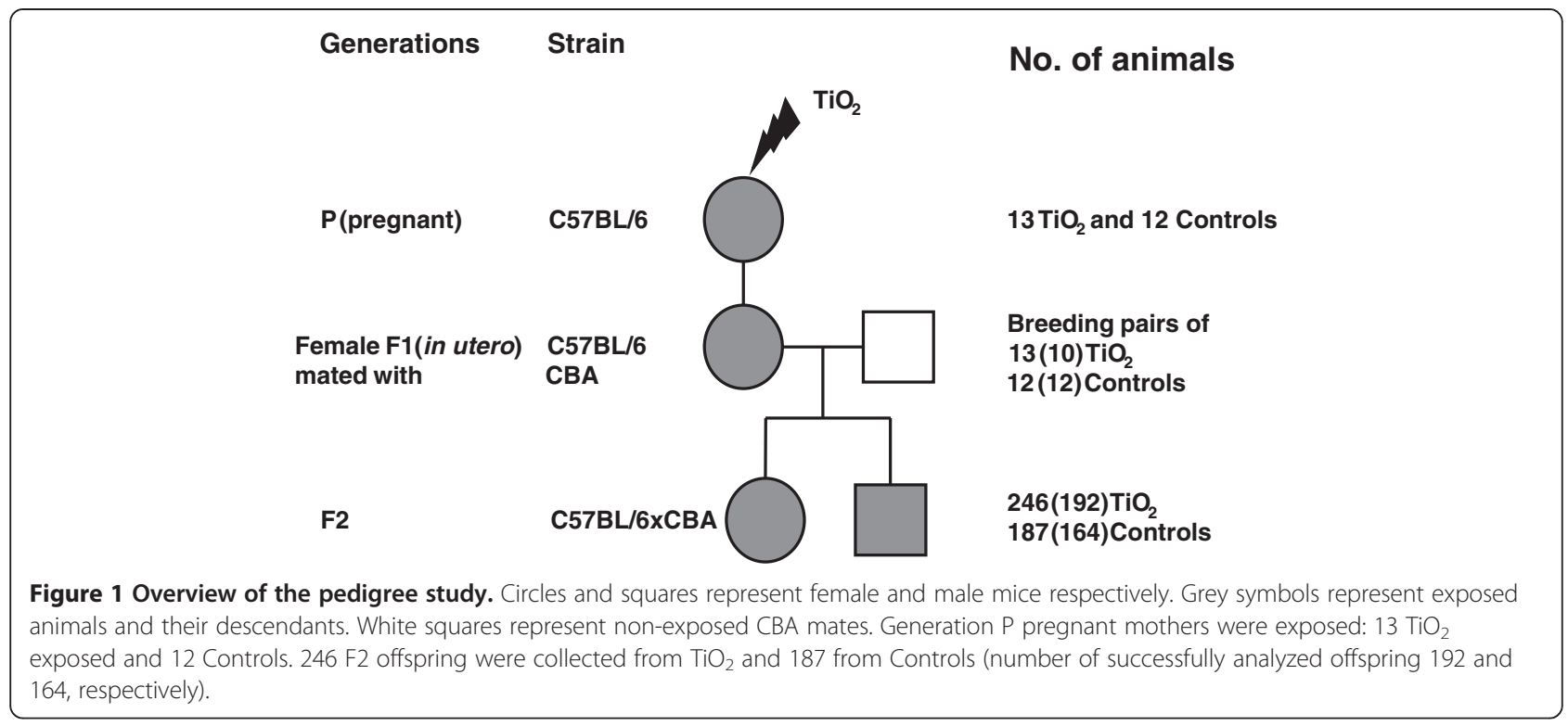

ESTR mutations have been suggested to be induced via polymerase pausing resulting from the presence of epigenetic changes or DNA damage such as oxidative stress, strand breaks or adducts elsewhere in the genome rather than by direct DNA damage [5]. We have reported that the inhalation of a total dose of $840 \mu \mathrm{g}$ UV-Titan per animal at GD8-18 induced persistent inflammation in the lungs of the time-mated $\mathrm{P}$ generation (Figure 1) $[9,24]$. Furthermore, 476 genes were found to be differentially expressed in the liver of newborn F1 generation females prenatally exposed to UV-Titan. We hypothesize that the transfer of inflammatory cytokines across the placenta may have caused this differential gene expression [10] since no $\mathrm{TiO}_{2}$ was detected in maternal liver, mother's milk or offspring liver [9].

ESTR mutation analysis is a sensitive method, enabling analysis under realistic exposure scenarios. An a priori power analysis showed that group size in the present study provided a $77 \%$ chance of detecting a 2 -fold increase in ESTR mutations at the 5\% significance level. The exposure and the estimated inhaled dose of $840 \mu \mathrm{g}$ used in this study is comparable to the permissible exposure limit by Danish Regulation and the exposure route (inhalation) is also relevant to environmental exposure [9]. As little as $54 \mu \mathrm{g}$ UV-Titan can induce inflammation in mouse lungs after one day [12,17]. Female germ cells enter meiotic prophase on $\sim$ GD13.5 [21]. In the present study female mice were prenatally exposed from GD8-18 ensuring that the period of mitotic germ cell division was targeted; these mothers were exposed to $\sim 458 \mu \mathrm{g}$ prior to GD13. Consequently, a high degree of inflammation was likely to be present at GD13.5, when oocytes cease to be susceptible to ESTR mutations [21,22].

In parallel with the present study (in the same laboratory and time period), ESTR germline mutations in male and female mice prenatally exposed to diesel exhaust particles (DEP) by inhalation were quantified [2]. Male germ cell mutation rates were significantly increased following exposure to DEP and may thus be regarded as a positive control for the ability to detect induced ESTR mutation. ESTR mutation rates were not significantly

Table 1 Summary of ESTR mutation rates in F2 offspring of prenatally exposed female C57BL/6 mice

\begin{tabular}{|c|c|c|c|c|c|c|}
\hline \multirow[t]{2}{*}{ Group } & \multirow[t]{2}{*}{ probe } & \multirow[t]{2}{*}{$N$ (F2 offspring) } & \multicolumn{2}{|c|}{ Mutant bands } & \multicolumn{2}{|c|}{ Mutation rate \pm SEM $\left(P\right.$ value $\left.{ }^{a}\right)$} \\
\hline & & & $\begin{array}{c}\text { Paternal } \\
\text { origin }\end{array}$ & $\begin{array}{c}\text { Maternal } \\
\text { origin }\end{array}$ & $\begin{array}{c}\text { Paternal } \\
\text { origin }\end{array}$ & $\begin{array}{c}\text { Maternal } \\
\text { origin }\end{array}$ \\
\hline Female controls & Ms6-hm & 164 & 11 & 5 & $0.0671 \pm 0.0002$ & $0.0305 \pm 0.0002$ \\
\hline Female controls & $H m-2$ & 164 & 9 & 7 & $0.0549 \pm 0.0004$ & $0.0427 \pm 0.0004$ \\
\hline Female controls & Total & 164 & 20 & 12 & $0.0610 \pm 0.0028$ & $0.0366 \pm 0.0030$ \\
\hline Female $\mathrm{TiO}_{2}$ exposed & Ms6-hm & 192 & 10 & 4 & $0.0521 \pm 0.0004$ & $0.0208 \pm 0.0002$ \\
\hline Female $\mathrm{TiO}_{2}$ exposed & $\mathrm{Hm}-2$ & 192 & 8 & 7 & $0.0417 \pm 0.0004$ & $0.0365 \pm 0.0003$ \\
\hline Female $\mathrm{TiO}_{2}$ exposed & Total & 192 & 18 & 11 & $0.0469 \pm 0.0107(P=0.84)$ & $0.0286 \pm 0.0133(P=0.79)$ \\
\hline
\end{tabular}

a Fisher's exact test 1-tailed. 
increased in germ cells of females prenatally exposed to DEP. To our knowledge, this is the only other study, which has investigated chemically induced ESTR mutations in prenatally exposed females. A recent study showed that dividing oocytes are susceptible to mutations in vivo. Prenatal exposure to 1 Gy of acute irradiation on GD12 resulted in a 1.94-fold increase in the ESTR mutation rate [22].

$\mathrm{NanoTiO}_{2}$ can induce DNA strand breaks and carcinogenic effects in vivo $[11,25,26]$. We recently reported that UV-Titan inhalation did not increase DNA strand breaks in the P or F1 generations [10], suggesting that genotoxic effects in offspring are negligible. Correspondingly, in the study of prenatal DEP exposure by [2], which showed ESTR instability in male offspring, the exposure also failed to increase DNA strand breaks in liver from newborns [27]. Epigenetic changes have been suggested as the underlying mechanism of ESTR instability $[5,22]$. A recent study found DNA deletions in mice prenatally exposed to nanoTiO ${ }_{2}$ [26]. However, the small effective sample size and the very large maternal dose used in the study hamper interpretation. The results on nanoTiO $\mathrm{Ti}_{2}$ induced mutations and genotoxicity are conflicting $[10,15,26]$. The various types of commercially available nano $\mathrm{TiO}_{2}$ also make it difficult to generalize. It is possible that NPs with very active surface chemistry, which produce more reactive oxygen species (ROS) or a large inflammatory response, could induce germline mutations. In the present study we have only assessed the effects of a single type of $\mathrm{TiO}_{2} \mathrm{NP}$. We are currently investigating the effects of prenatal exposure to nanosized carbon black Printex90, a more efficient generator of ROS than both DEP and nanoTiO 2 [12] to further address the question of female susceptibility to NPs. The present study indicates that prenatal exposure to nano$\mathrm{TiO}_{2}$ does not affect female germline ESTR mutation frequency.

\section{Competing interests}

The authors declare that they have no competing interests.

\section{Acknowledgements}

The authors gratefully acknowledge statistical support from Andrew Williams and technical assistance from Michael Guldbrandsen, Gitte Kristiansen and Colin Davis. This work was supported by the Danish Centre for Nanosafety from the Danish Working Environment Research Fund.

\footnotetext{
Author details

'The National Research Centre for the Working Environment, Copenhagen, Denmark. ${ }^{2}$ National Food Institute, Technical University of Denmark, Søborg, Denmark. ${ }^{3}$ Environmental Health Science and Research Bureau, Health Canada, Ottawa, Canada. ${ }^{4}$ Department of Micro- and Nanotechnology, Technical University of Denmark, Lyngby, Denmark.
}

\section{Authors' contributions}

AMZB was substantially involved in the design of the study, collected animal tissue, processed samples and performed the electrophoresis, blot probing, image processing, mutation scoring, statistical analysis and drafted the manuscript. TS re-probed and developed images for a large portion of blots and revised the manuscript. PJ exposed the $\mathrm{P}$ generation mice, assigned F1 offspring for the current study and revised the manuscript critically. KSH was project manager of the study and revised the manuscript critically. HW was substantially involved in the design of the study and revised the manuscript critically. CLY was substantially involved in the design of the study, scored mutations and revised the manuscript critically. UBV was substantially involved in the design of the study and revised the manuscript critically. All authors read and approved the final version of the manuscript.

Received: 9 November 2011 Accepted: 14 May 2012

Published: 1 June 2012

\section{References}

1. Sram RJ, Binkova B, Rossner P, Rubes J, Topinka J, Dejmek J: Adverse reproductive outcomes from exposure to environmental mutagens. Mutat Res 1999, 428:203-215.

2. Ritz C, Ruminski W, Hougaard KS, Wallin H, Vogel U, Yauk CL: Germline mutation rates in mice following in utero exposure to diesel exhaust particles by maternal inhalation. Mutat Res 2011, 712:55-58.

3. Somers CM, McCarry BE, Malek F, Quinn JS: Reduction of particulate air pollution lowers the risk of heritable mutations in mice. Science 2004, 304:1008-1010.

4. Somers CM, Cooper DN: Air pollution and mutations in the germline: are humans at risk? Hum Genet 2009, 125:119-130.

5. Yauk C, Polyzos A, Rowan-Carroll A, Somers CM, Godschalk RW, Van Schooten FJ, Berndt ML, Pogribny IP, Koturbash I, Williams A, Douglas GR, Kovalchuk O: Germ-line mutations, DNA damage, and global hypermethylation in mice exposed to particulate air pollution in an urban/industrial location. Proc Natl Acad Sci U S A 2008, 105:605-610.

6. Yauk CL, Fox GA, McCarry BE, Quinn JS: Induced minisatellite germline mutations in herring gulls (Larus argentatus) living near steel mills. Mutat Res 2000, 452:211-218.

7. Kreyling WG, Semmler-Behnke M, Seitz J, Scymczak W, Wenk A, Mayer P, Takenaka S, Oberdorster G: Size dependence of the translocation of inhaled iridium and carbon nanoparticle aggregates from the lung of rats to the blood and secondary target organs. Inhal Toxicol 2009, 21 (Suppl 1):55-60.

8. Sadauskas E, Jacobsen NR, Danscher G, Stoltenberg M, Vogel U, Larsen A, Kreyling W, Wallin $\mathrm{H}$ : Biodistribution of gold nanoparticles in mouse lung following intratracheal instillation. Chem Cent J 2009, 3:16.

9. Hougaard KS, Jackson P, Jensen KA, Sloth JJ, Loschner K, Larsen EH, Birkedal RK, Vibenholt A, Boisen AM, Wallin H, Vogel U: Effects of prenatal exposure to surface-coated nanosized titanium dioxide (UV-Titan). A study in mice. Part Fibre Toxicol 2010, 7:16

10. Jackson P, Halappanavar S, Hougaard KS, Williams A, Madsen AM, Lamson JS, Andersen O, Yauk C, Wallin $\mathrm{H}$, Vogel U: Maternal inhalation of surface-coated nanosized titanium dioxide (UV-Titan) in C57BL/6 mice: Effects in prenatally exposed offspring on hepatic DNA damage and gene expression. Nanotoxicology 2012, doi:10.3109/17435390.2011.633715. in press.

11. Oberdorster G, Ferin J, Lehnert BE: Correlation between particle size, in vivo particle persistence, and lung injury. Environ Health Perspect 1994, 102(Suppl 5):173-179.

12. Saber AT, Jensen KA, Jacobsen NR, Birkedal R, Mikkelsen L, Moller P, Loft S, Wallin $\mathrm{H}$, Vogel $\mathrm{U}$ : Inflammatory and genotoxic effects of nanoparticles designed for inclusion in paints and lacquers. Nanotoxicology 2012, 6:453-71. doi:10.3109/17435390.2011.587900.

13. Saber AT, Koponen IK, Jensen KA, Jacobsen NR, Mikkelsen L, Moller P, Loft S, Vogel U, Wallin H: Inflammatory and genotoxic effects of sanding dust generated from nanoparticle-containing paints and lacquers. Nanotoxicology 2012, doi:10.3109/17435390.2011.620745. in press.

14. Baan R, Straif K, Grosse Y, Secretan B, El GF, Cogliano V: Carcinogenicity of carbon black, titanium dioxide, and talc. Lancet Oncol 2006, 7:295-296.

15. Johnston HJ, Hutchison GR, Christensen FM, Peters S, Hankin S, Stone V: Identification of the mechanisms that drive the toxicity of $\mathrm{TiO}(2)$ particulates: the contribution of physicochemical characteristics. Part Fibre Toxicol 2009, 6:33.

16. Bermudez E, Mangum JB, Wong BA, Asgharian B, Hext PM, Warheit DB, Everitt Jl: Pulmonary responses of mice, rats, and hamsters to subchronic inhalation of ultrafine titanium dioxide particles. Toxicol Sci 2004, 77:347-357. 
17. Saber AT, Jacobsen NR, Mortensen A, Szarek J, Jackson P, Madsen AM, Jensen KA, Koponen IK, Brunborg G, Gutzkow KB, Vogel U, Wallin H: Nanotitanium dioxide toxicity in mouse lung is reduced in sanding dust from paint. Part Fibre Toxicol 2012, 9:4.

18. Dubrova YE, Plumb M, Brown J, Fennelly J, Bois P, Goodhead D, Jeffreys AJ: Stage specificity, dose response, and doubling dose for mouse minisatellite germ-line mutation induced by acute radiation. Proc Natl Acad Sci U S A 1998, 95:6251-6255.

19. Hedenskog M, Sjogren M, Cederberg H, Rannug U: Induction of germlinelength mutations at the minisatellites PC-1 and PC-2 in male mice exposed to polychlorinated biphenyls and diesel exhaust emissions. Environ Mol Mutagen 1997, 30:254-259.

20. Adler ID, Carere A, Eichenlaub-Ritter U, Pacchierotti F: Gender differences in the induction of chromosomal aberrations and gene mutations in rodent germ cells. Environ Res 2007, 104:37-45.

21. McLaren A: Germ and somatic cell lineages in the developing gonad. Mol Cell Endocrinol 2000, 163:3-9.

22. Barber RC, Hardwick RJ, Shanks ME, Glen CD, Mughal SK, Voutounou M, Dubrova YE: The effects of in utero irradiation on mutation induction and transgenerational instability in mice. Mutat Res 2009, 664:6-12.

23. Bouzeid Ali HE, Barber RC, Dubrova YE: The effects of maternal irradiation during adulthood on mutation induction and transgenerational instability in mice. Mutat Res 2012, 732:21-25.

24. Halappanavar S, Jackson P, Williams A, Jensen KA, Hougaard KS, Vogel U, Yauk CL, Wallin H: Pulmonary response to surface-coated nanotitanium dioxide particles includes induction of acute phase response genes, inflammatory cascades, and changes in microRNAs: A toxicogenomic study. Environ Mol Mutagen 2011, 52:425-439.

25. Borm PJ, Schins RP, Albrecht C: Inhaled particles and lung cancer, part B: paradigms and risk assessment. Int I Cancer 2004, 110:3-14.

26. Trouiller B, Reliene R, Westbrook A, Solaimani P, Schiestl RH: Titanium dioxide nanoparticles induce DNA damage and genetic instability in vivo in mice. Cancer Res 2009, 69:8784-8789.

27. Hougaard KS, Jensen KA, Nordly P, Taxvig C, Vogel U, Saber AT, Wallin H: Effects of prenatal exposure to diesel exhaust particles on postnatal development, behavior, genotoxicity and inflammation in mice. Part Fibre Toxicol 2008, 5:3.

doi:10.1186/1743-8977-9-19

Cite this article as: Boisen et al: $\mathrm{NanoTIO}_{2}$ (UV-Titan) does not induce ESTR mutations in the germline of prenatally exposed female mice.

Particle and Fibre Toxicology 2012 9:19.

\section{Submit your next manuscript to BioMed Central and take full advantage of:}

- Convenient online submission

- Thorough peer review

- No space constraints or color figure charges

- Immediate publication on acceptance

- Inclusion in PubMed, CAS, Scopus and Google Scholar

- Research which is freely available for redistribution 